\title{
Sedimentology and biostratigraphy of the Early-Middle Miocene transition in NW Transylvanian Basin (Pâglişa and Dej sections)
}

\author{
Claudia BELDEAN ${ }^{1 *}$, Răzvan BERCEA² \& Sorin FILIPESCU ${ }^{1}$ \\ ${ }^{1}$ Department of Geology, Babeş-Bolyai University, Kogălniceanu 1, 400084, Cluj-Napoca, Romania \\ ${ }^{2}$ OMV Petrom S.A., Coralilor 22, Sector 1, 013329, Bucharest, Romania
}

Received March 2013; accepted July 2013

Available online August 15, 2013

DOI: http://dx.doi.org/10.5038/1937-8602.58.1.5

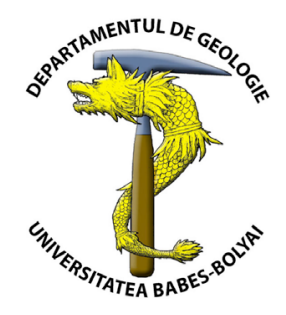

\begin{abstract}
The Early - Middle Miocene transition can be studied in several sections from the north-western Transylvanian Basin, across the boundary between the Hida and Dej Formations. The Pâglişa and Râpa Dracului (Dej locally outcrop) sections offer a very good record of the changes in the sedimentary facies and micropaleontological content across the boundary. The lower parts of the sections display the upper Hida Formation with prodelta fine-grained sediments covered by coarser grained sediments related to a delta front progradation. Four sedimentary facies associations have been separated based on grain size and associated sedimentary structures. Micropaleontological assemblages are moderately to poorly preserved, with a low abundance and diversity. Planktonic Streptochilus pristinum is the main taxon associated with rare $(<10 \%)$ calcareous benthic foraminifera (Bulimina, Bolivina, Cibibicidoides). The Dej Formation consists of stacked channel lag deposits associated with lateral accretion bars and crevasse splays followed by fall-out tuffs and redeposited low density tuffites interbedded with low density fine siliciclastics. The deposits of Dej Formation from the investigated areas were separated in four facies associations based on grain size/petrography and primary sedimentary structures. Micropaleontological assemblages contain typical early Badenian planktonic foraminifera (species of Orbulina, Praeorbulina, Globigerinoides, and Globorotalia) associated to the main phase of the marine transgresion from the beginning of the Middle Miocene.
\end{abstract}

Keywords: Early-Middle Miocene boundary, Transylvanian Basin, planktonic foraminifera, sedimentology, progradation

\section{INTRODUCTION}

The sedimentary fill of the Transylvanian Basin can be separated into four mega-sequences deposited during the Late Cretaceous to Late Miocene (Krézsek and Bally, 2006). The Lower Miocene mega-sequence (Fig. 1) is represented by the Hida Formation (Hofmann, 1879; Koch, 1900) and its equivalents consisting of deep water turbidites in the north, followed by coarsegrained fan deltas towards south. These formations were deposited in a flexural basin developed in front of the uplifting Carpathian Pienides in the north (Tischler, 2005; Krézsek and Bally, 2006). Fan-deltas represent the falling stage, closing the sequence and are related to the uplifts in the source areas. The early stage of the following relative sea-level rise (low stand of the fourth megasequence) can be recorded in the marine sediments covering the fan deltas (Beldean et al., 2010). A regional transgression during the Middle Miocene established relatively deep marine settings throughout the basin with mixed carbonate-siliciclastics platforms near the margins and siliciclastics (hemipelagites) environments in deeper areas (Filipescu and Gîrbacea, 1997; Krézsek et al., 2010). At this time, the Transylvanian Basin was well connected with the Mediterranean and there was a great similarity in their paleontological record. Transgression was balanced by the high sedimentary input provided by an important volcanic activity during the deposition of the Dej Tuff(14.38-14.37 Ma - de Leeuw, 2011; 14.8-15.1 Ma - Szakács et al., 2012).

The Lower - Middle Miocene boundary is widely accepted to be approximated by the Praeorbulina datum (Rio et al., 1997) and is consequently considered to correspond to the base of the Langhian, with an age of $15.97 \mathrm{Ma}$ (Hilgen et al., 2012). However, recent approach suggests that the first occurrence of this taxon is not a suitable marker not only because of the controversial taxonomic concepts, but also because of its rarity and discontinuous distribution (Turco et al., 2011). Because the Langhian GSSP has not been defined so far, we will consider the traditional Praeorbulina event as marker for the Early-Middle Miocene boundary (Popescu, 1975; Rögl, 1985; Lourens et al., 2004; Kováčová and Hudáčková, 2005; Rögl et al., 2008). However, if the boundary would be correlated with the beginning of a new sequence, the occurrence of biserial planktonic Streptochilus (Beldean et al., 2010) prior to Praeorbulina suggests a possible placement of the boundary in a lower position.

The Early-Middle Miocene transition in the Transylvanian Basin was stratigraphically characterized by Popescu (1970), 


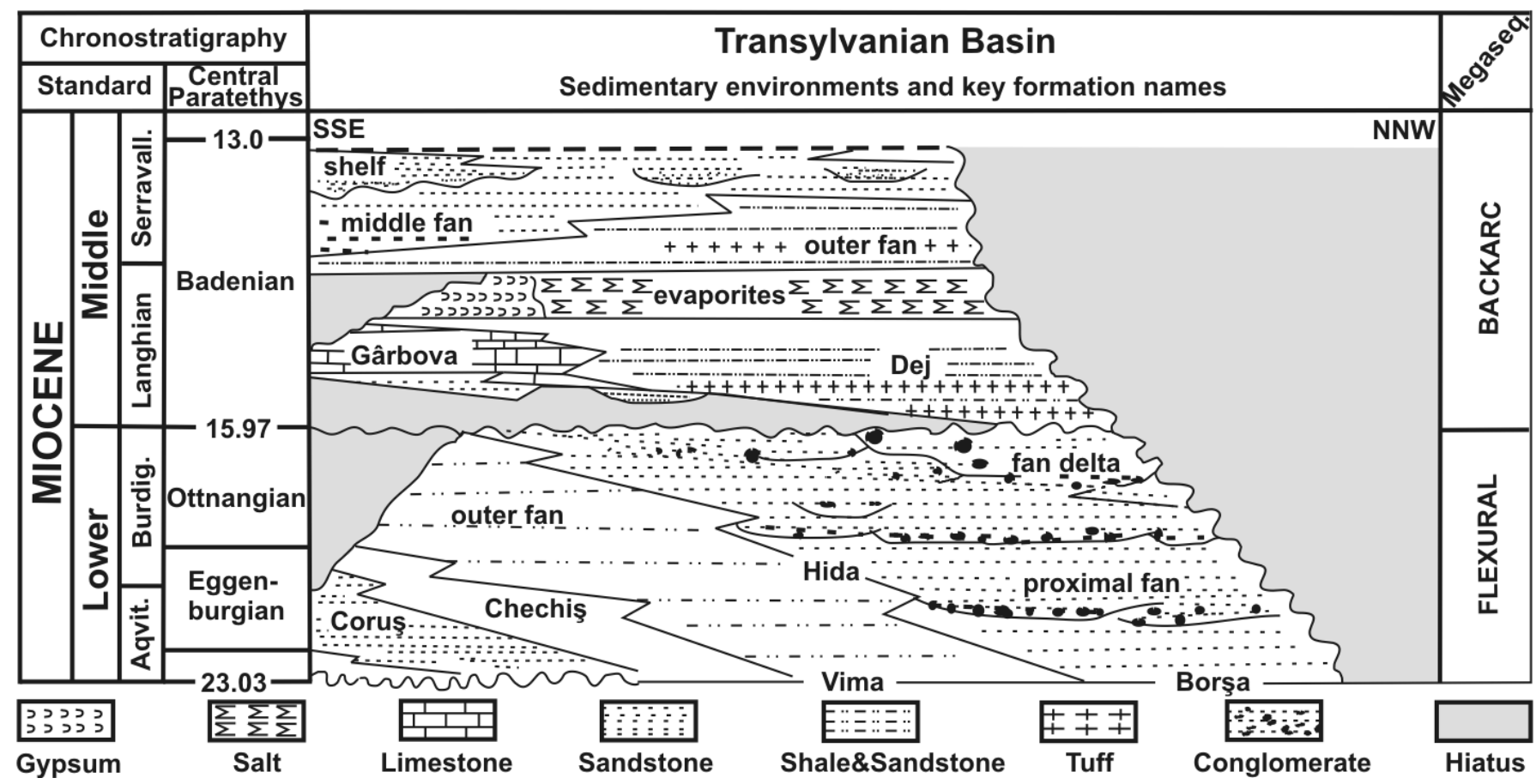

Fig. 1. Litho-stratigraphical units in the Transylvanian Basin during Lower and Middle Miocene (modified after Krézsek and Bally, 2006).

Beldean et al. (2010, 2012) and de Leeuw et al. (2013). This transition can be followed trough three successive biozones which can be identified in the studied area (Pâglişa and Dej section) and also in Ciceu-Giurgești section (de Leeuw et al., 2013). In all cases the assemblages of the lowermost part are dominated by biserial planktonic foraminifera of the Early Miocene Streptochilus pristinum Biozone (Beldean et al., 2010). Those are followed by conglomerate bed with foraminifera of the early Badenian Praeorbulina glomerosa Biozone. At Pâglişa and Dej outcop the Praeorbulina glomerosa Biozone was not identified due to the covered area. All sections end with the Orbulina suturalis Biozone.

Our aim was to point out the changes in sedimentary facies and micropaleontological record across the Early-Middle Miocene boundary. Additionally, we considered the data published on calcareous nannoplankton by Chira et al. (2000) for Pâglişa and by Dumitrică et al. (1975), Mészáros and Filipescu (1991), and Chira and Bâlc (2002) for Dej.

\section{MATERIAL AND METHODS}

The investigated sections are located at Pâglişa, at about $45 \mathrm{~km}$ north from Cluj-Napoca (N 470'23.87', E 2338'24.75”) and at Râpa Dracului in Dej (N 47008'83.01", E 2351'56.90”) (Fig. 2).

The sedimentological interpretation relies on outcrop measurements and observations, while the micropalentological data were collected from the fine siliciclastics of the Hida and Dej formations. Twelve samples from Pâglișa were analyzed for foraminifera and fifteen for calcareous nannoplankton in the Hida Formation (N1-15), while ten samples were studied for foraminifera content in the Dej Formation (D1-10). In parallel, 39 samples were investigated for foraminifera content from Râpa Dracului (Rp1-39).

Foraminifera samples were processed by standard micropaleontological methods, the specimens were recovered from the $63 \mu \mathrm{m}$ sieve and studied under stereomicroscope and SEM. Calcareous nannofossils were processed by standard smear slide technique and examined under the light microscope.

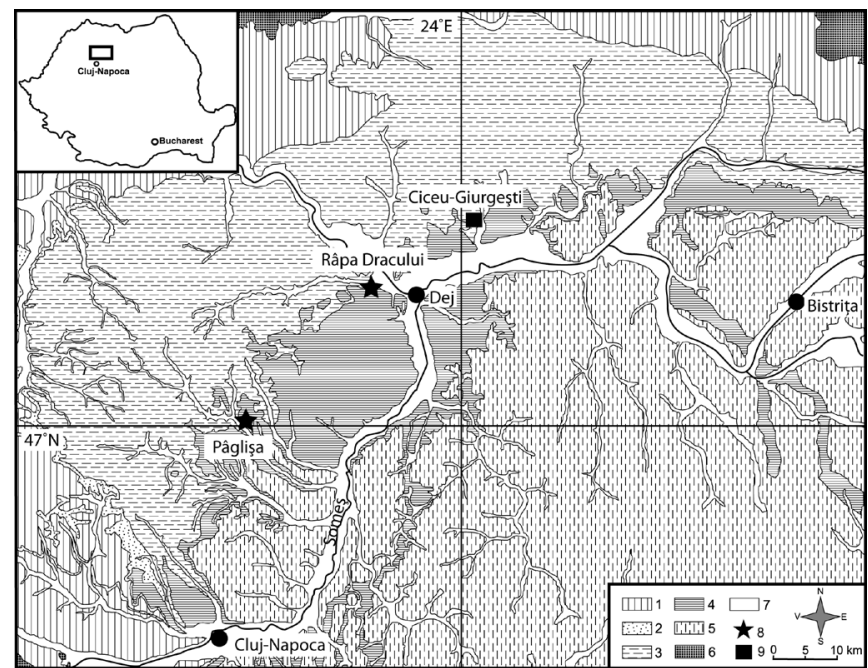

Fig. 2. Location of investigated section on the simplified geological map. 1 -Paleogene, 2 -Lower Miocene shallow marine formations, 3 - Lower Miocene deep marine formation, 4-Badenian, 5-Sarmatian, 6-metamorphics, 7-Quaternary, 8-investigated sections, 9-previous investigated section (modified after Beldean et al. 2010).

\section{RESULTS}

\section{Biostratigraphy}

The Early/Middle Miocene (Burdigalian/Langhian) boundary is biostratigraphically associated to the FO of Praeorbulina marking the boundary between biozones M4 and M5 (Berggren et al., 1995) (Fig. 3). Based on calcareous nannofossil the boundary can be roughly approximated by the LO of Helicosphaera ampliaperta Bramlette and Wilcoxon, 1967 marking the base of biozone NN5 (Martini, 1971; Maiorano and Monechi, 1998; Mandur, 2009).

Based on the index fossil Helicosphaera ampliaperta identified in the lower part of Pâglişa section, the Late Burdigalian NN4 Zone (Martini, 1971) was establish. This is in accordance with previous studies, which indicate NN4 Zone for the top of the Hida Formation (Mészáros et al., 1976; Beldean et al, 2010; 2012). 


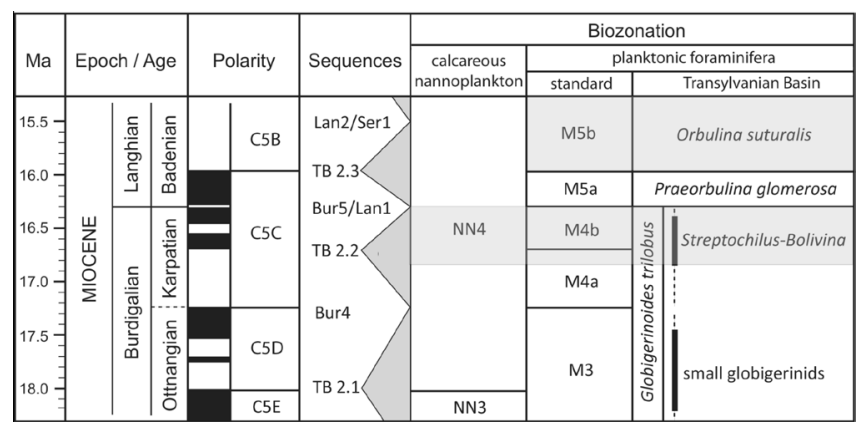

Fig. 3. Lower and Middle Miocene Biozones based on the foraminifera and calcareousnannoplankton in the Transylvanian Basin (gray hatch - identified biozone in this study) (zones based on Popescu, 1975; Haq et al., 1988; Berggren, 1995; Hardenbol et al., 1998; Rögl et al., 2008; Beldean et al., 2010).

In the upper part of the same section, Chira et al. (2000) identified assemblages belonging to NN5 and NN6 zones (partim). At Dej section, Dumitrică et al. (1975) and Mészáros and Filipescu (1991) identified taxa belonging to NN5 Sphenolithus heteromorphus Zone (Martini, 1971) proving the Early Badenian age of the tuff.

Foraminifera assemblages are comparable in both investigated sections. The samples from the Hida Formation (Fig. 4) contain almost exclusively small biserial planktonics (Streptochilus pristinum Brönnimann and Resig, 1971) and a few specimens of Bolivina dilatata dilatatai Reuss, 1850, Bulimina elongata d'Orbigny, 1826, and Cibicidoides sp. (P1. I), belonging to the Streptochilus-Bolivina Biozone (Beldean et al., 2010), located below the first occurrence of typically Middle Miocene Praeorbulina.

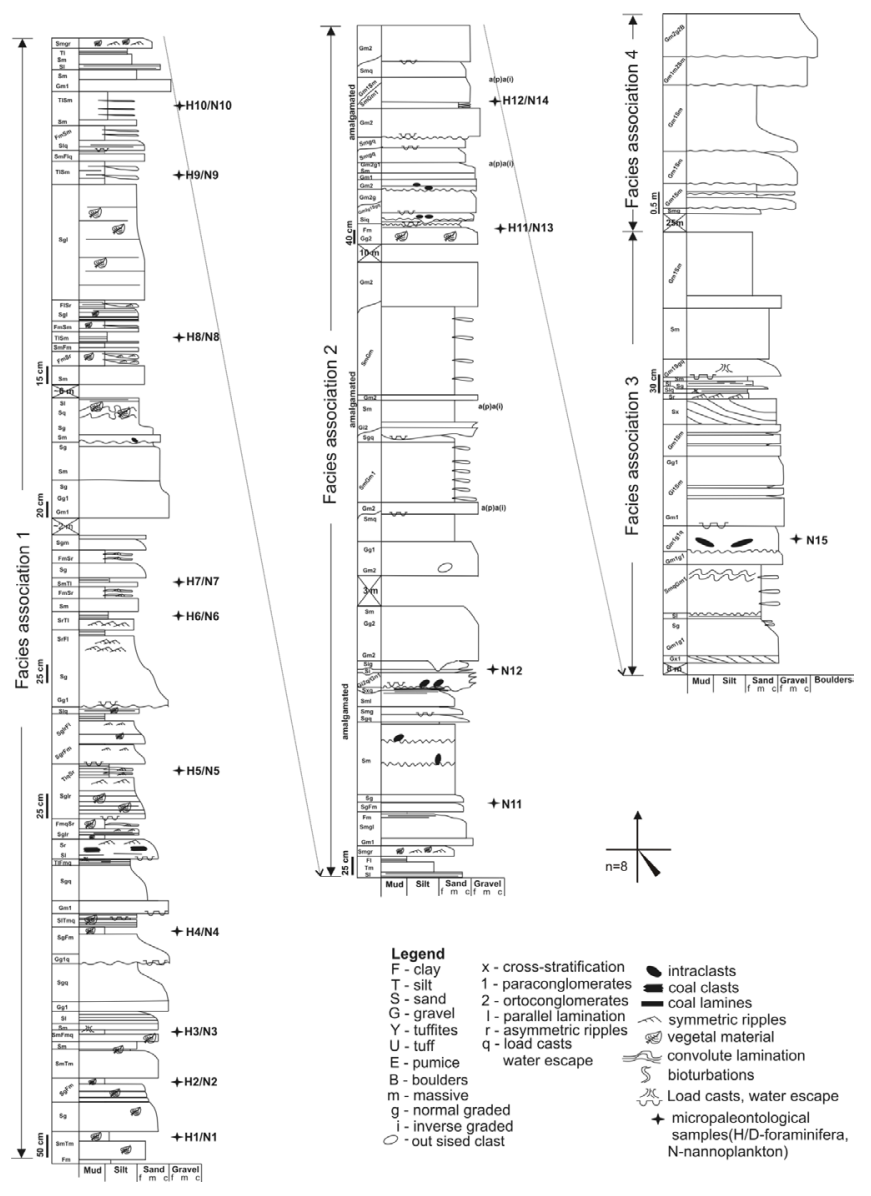

Fig. 4. Sedimentary log for Hida Formation at Pâglişa.
The biserials seem to be associated with a transgressive event, considered here as belonging to the TB2.2 cycle of Haq et al. (1988) and Bur4 sequence of Hardenbol et al. (1998) (Fig. 3).

Miocene Streptochilus spp. have been described as tropical to warm-subtropical forms (Brönnimann and Resig, 1971; Kennett and Srinivasan, 1983; Resig, 1989), but they have been reported from the northernmost Atlantic Ocean (Flower, 1999) through the Bahamas Bank (Kroon et al., 2000), the equatorial western Pacific (Premoli-Silva and Violanti, 1981; Resig, 1989) and the eastern Indian Ocean (Resig, 1989). High abundances of biserial planktonic foraminifera are indicative of eutrophic waters in the Paleogene (Hallock et al., 1991), while high abundances of Miocene - Pliocene Streptochilus species were correlated with high accumulation rates of plankton (Resig, 1989). In Transylvanian Basin, the hypothesis of eutrophic waters seems to fit better, because an important planktonic bloom was recorded only subsequently, related to the advancing Middle Miocene transgression.

The first evidences of Middle Miocene fauna starts with samples D1 at Pâglişa and Rp 34 at Dej (Figs. 5-6). The samples collected from the Dej Formation show a high abundance of planktonic foraminifera, typical for the early Badenian (Langhian). Praeorbulina glomerosa (Blow, 1956) and Orbulina suturalis Brönnimann, 1951 occur together with Globigerina tarcahanensis Subbotina and Kutsieva, 1950, Globigerinoides quadrilobatus (d'Orbigny, 1846), Globigerinoides trilobus (Reuss, 1850), Globorotalia mayeri Cushman and Ellisor, 1939, Globoquadrina sp. (Pl. II). Unfortunately, the first occurrence of Praeorbulina glomerosa was not identified due to the covered area in both sections, but this event was well recorded not very far, at Ciceu-Giurgeşti (N 47¹4'43.764'; E 2402'3.768'" - Popescu, 1970; Beldean et al., 2010; de Leeuw, 2011; de Leeuw et al., 2013). These assemblages are the result of a marine invasion is associated with Badenian transgression, which covered almost the whole Central Paratethys coming firstly with marine low latitude planktonic organisms. This transgression can clearly be correlated to the global sea level cycle TB2.3 of Haq et al. (1988) and Bur5/ Lan 1 sequence of Hardenbol et al. (1998) (Fig. 3).

Planktonic foraminifera assemblages from Dej Formation are associated with the main phase of transgression, which probably led oligotrophic conditions with stable environmental parameters. Similar assemblages were identified in the lower Badenian in Austria where the identified foraminifera indicated warm-temperate waters (Harzhauser et al., 2003).

\section{SEDIMENTOLOGY}

Four facies associations have been described for the Hida Formation based on sedimentological descriptions. Three facies associations were interpreted for the Dej Formation as mixed volcanoclastic/siliciclastic submarine channels to fall-out tuffs and redeposited low density turbiditic tuffites and fine grained siliciclastics.

\section{Hida Formation}

The facies associations identified for the Hida Formation at Pâglişa (FA1 to FA4; Fig. 4) was described based on the grain size and associated sedimentary structures. The facies associations identified at Râpa Dracului (Dej) section are also described below (FA1 and FA4; Fig. 6):

a) Facies association 1 (FA1)

Description. It was identified in the lower half of Pâglişa and lower part of Râpa Dracului outcrops. This facies association 


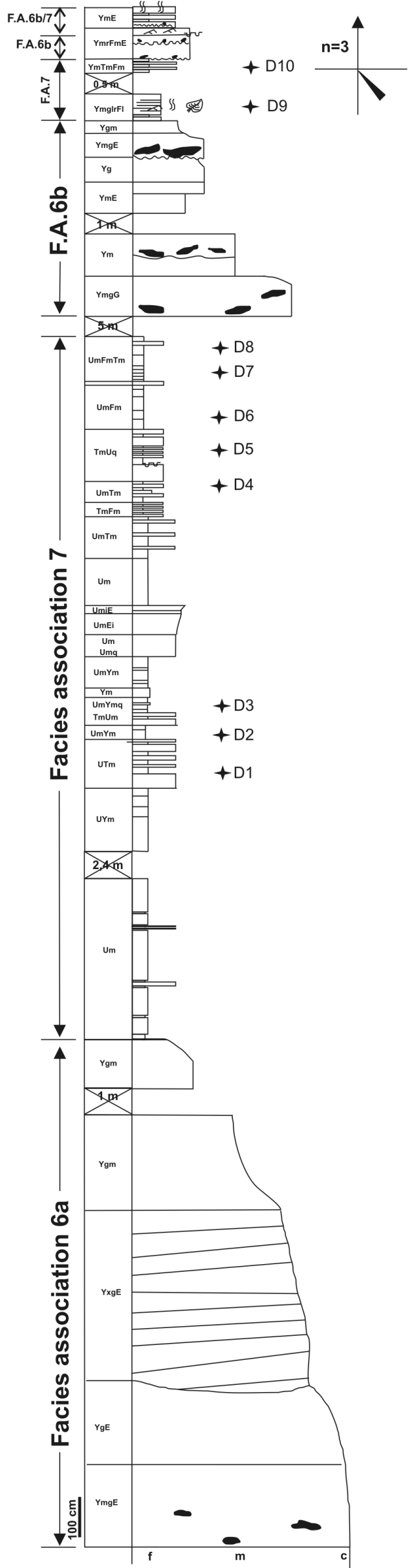

Fig. 5. Sedimentary log for Dej Formation at Pâglişa (for legend see Fig. 4). consists of dark grey mudstones, siltstones that are massive and parallel laminated (with organic material debris). The thin yellowish fine to fine-medium sandstones beds can be massive or with ripple marks (e.g., lenticular ripples, Pl. III, Fig. 1; Pl. IV, Figs. 1-2). The thicker yellowish fine to medium sandstones are massive and normal graded (Pl. IV, Figs. 3, 7, 8) with ripple marks, convolute structures and horizontal laminations (with organic material debris) locally with coal (lignite) chips (Pl. IV, Fig. 4) and mudstones rip-up clasts (Pl. IV, Fig. 7). Fine conglomerates or sandy fine conglomerates are present as well at the base of the sedimentary beds. Erosional scours, water escape and load casts are present at the base of massive to normally graded sandy fine conglomerates. Water escape, load casts are common at Pâglişa but not at Râpa Dracului section. No bioturbations have been clearly observed at Pâglișa, while vertical/horizontal burrows are extensively present at Râpa Dracului (Pl. IV, Figs. 1-3, 7).

Facies interpretation. The accumulation of fine sediments was produced through low density turbiditic flows, maybe in a prodelta environment (Tanaka and Maejima, 1995). The massive muds are related to a quiet settling, while the presence of laminations indicates lower flow regimes.

Coal chips indicate a nonmarine source, probably delivered by distributary channels (Gani and Bhattacharya, 2007) and were redistributed seaward (Pl. IV, Fig. 4). The sandstones beds could be interpreted as belonging to the fan lobes associated with minor channels from the delta front. The abundant load casts and no obvious bioturbation at Pâglişa, low abundance of microfossils, suggest high sedimentation rates (Bhattacharya and Davies, 2001). The extensive presence of the vertical/horizontal burrows in the FA1 from Râpa Dracului points towards a low energy environment, abundant in nutrients, disturbed by the sandstones and sandy fine conglomerates channels/lobes (Pl. IV, Figs. 1, 3, 7). This could be explained by the more distal position of the Râpa Dracului section compared to Pâglişa.

b) Facies association 2 (FA2)

Description. This facies it is characterized by coarser sandstones compared to FA1 with numerous sandy fine conglomerates intercalations. Few massive lenticular mudstones beds with planktonic and benthic foraminifera are present (Pl. III, Fig. 5; Pl. V, Fig. 10).

Rip-up clasts and scour structures are present at the base of coarse channels-deposits (Pl. III, Fig. 2). Multiple amalgamations (Pl. III, Fig. 4) are characteristic for this facies association. The sandstones are massive or normal graded sometimes with horizontal lamination (Pl. III, Fig. 2), ripple and a thin scoured fine sand dune. Imbrications [a(p)a(i) type] develop in the fine conglomerates beds and suggests a paleoflow towards the South-East. The conglomerates beds are massive, normally and reversely graded with numerous scour structures. Deformational structures (flames-like structures) (Pl. III, Fig. 3) are present between the sandstones or between the sandy fine conglomerates beds. On a larger scale normal graded fine conglomerates, sandy conglomerates to medium-fine sandstones normally graded cycles can be observed (Pl. V, Fig. 10).

Facies interpretation. The gravitational sediment flows that produced this deposits range from high dense turbiditic flows (Mulder and Alexander, 2001) or concentrated flows to low dense turbiditic flows. Oversized clasts can be the result of flow partitioning on inclined paleogeomorphology as a product of debris-falls. This facies association probably can be interpreted as belonging to a middle-distal delta front made of sandy thin conglomerates, sandstones lobes and associated channels. 

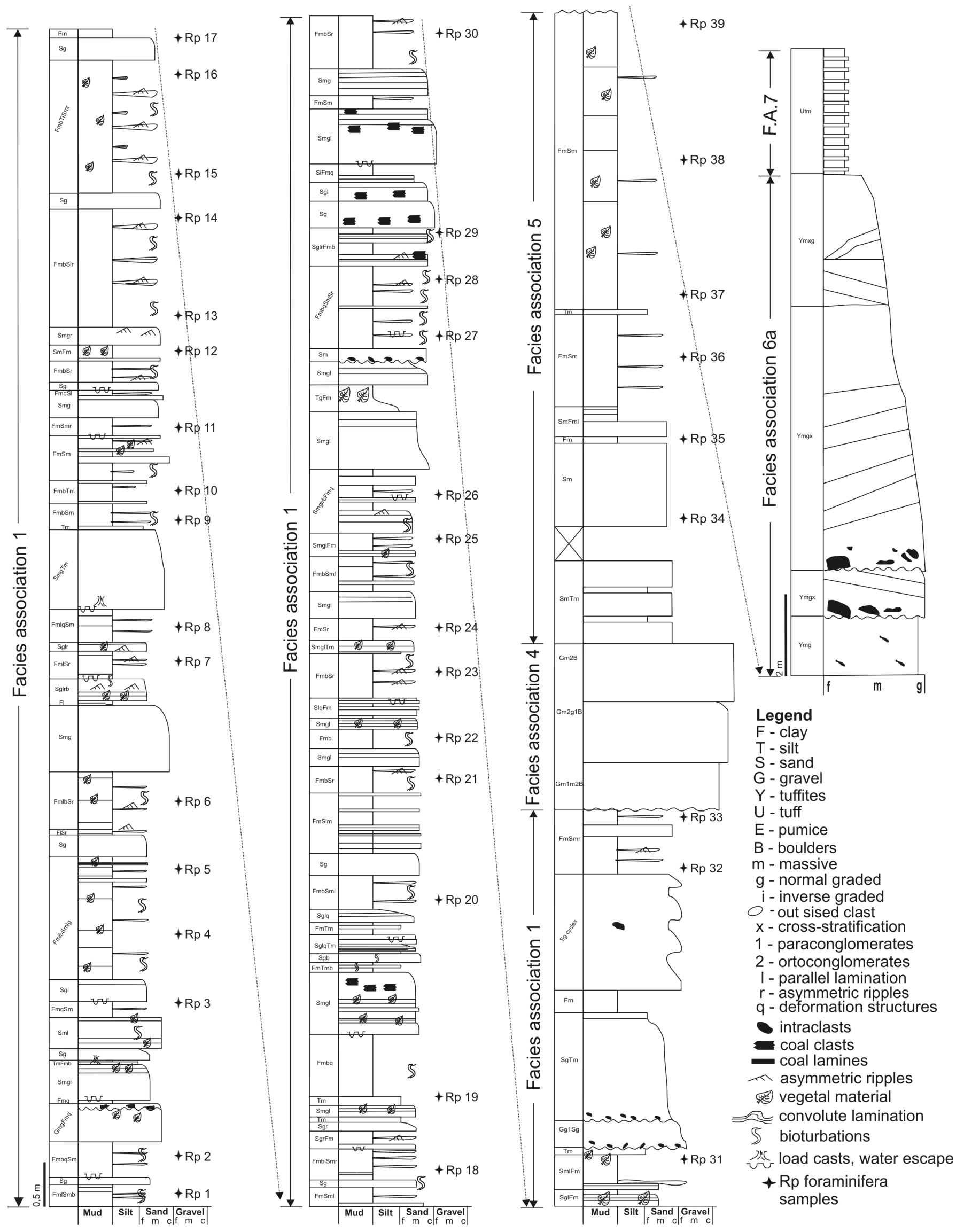

Fig. 6. Sedimentary log for Dej and Hida formations at Dej (Râpa Dracului). 
c) Facies associations 3 (FA3)

Description. This facies association comprises sandy fine conglomerates, fine conglomerates and fine to coarse sandstones. It starts with a tabular single set dune (Fig. 4) with fine gravelly sandstones. The thickness of the tabular set dune decreases in (from $10 \mathrm{~cm}$ to $5 \mathrm{~cm}$ ) down-current. The second single set dune (coarse sandstones with fine conglomerates) is thicker, with epsilon set geometry $(\sim 60 \mathrm{~cm})$ and its thickness decreases down-current (Pl. III, Fig. 7). The foresets points toward a southeast paleoflow direction. A very small amount of mollusk shell bioclasts develops on the foresets. Massive to normally graded sandy conglomerates occur together with massive and normal graded sandstones. Water escape, load casts, scour marks, horizontal lamination, climbing ripples are present in some sandstones deposits. The sandy fine conglomerates commonly have rip-up clasts with load casts (,flames") between the bed contacts.

Facies interpretation. The first dune tabular geometry suggests sedimentation based on traction currents with fine gravels rolling down on foresets, which create reverse grading. The second dune is of low angle and has epsilon geometry. This type of geometry suggests sedimentation from traction and suspension (indicates higher velocities than the tabular one). The climbing ripples on the second dune can be a good indicator of a (?) hyperpycnal flow (Mulder and Alexander, 2001). "Flames" can point out the paleoflow direction (Nort to South). These sedimentary structures represent the key for the facies association interpretation. They might point out for a middle-proximal delta front.

\section{d) Facies association 4 (FA4)}

Description. The fourth facies association was identified on the top of the exposed Hida Formation, outcrop at Pâglişa and Râpa Dracului. It is represented by massive to normally graded coarsegrained deposits (from fine to medium-coarse pebbles, cobbles and boulders - conglomerates). At Pâglişa (Pl. V, Fig. 1) it occurs as multiple lenses ( $\mathrm{cm}$ to $\mathrm{dm}$ ) with a coarsening upward trend of coarse gravels (orthoconglomerates and very few paraconglomerates), sandy conglomerates in a sandy matrix. At Râpa Dracului (Pl. IV, Fig. 5) this facies association is made of closely stacked (around $2.5 \mathrm{~m}$ ) coarse grained deposits (only orthoconglomerates with a coarsening upward trend), with a sheet like geometry.

Facies interpretation. The clast-supported texture and the mud-free nature of the matrix point towards a hyperconcentrated flow (sensu Mulder and Alexander, 2001) or cohensionelss debris flow. The normal graded beds represent sedimentation from highdensity turbidity currents (Lowe, 1982) or concentrated flows (Mulder and Alexander, 2001). These conglomerates are rounded, probably due to the processing in a beach environment prior to resedimentation seaward (Leigh and Hartley, 1992). The thick FA4 and also the thin sandstones beds from Râpa Dracului compared to Pâglişa are probably because of the different positions related to the source area. The presence of this FA 4 at the top of Hida Formation points out to a coarsening upward trend which suggests a progradational pattern.

\section{Dej Formation}

The lower part of the Middle Miocene (Dej Formation) consists of white-greenish tuffites (with a grain size between lapilli and coarse to medium ash), pumice, and fine green tuffs. Also, siliciclastic dark-grey low and high density turbiditic flows associated deposits are intercalated. Several facies associations
(FA5, FA6a, FA6b and FA7) have been separated based on grain size/petrography and primary sedimentary structures (Figs. 4-5).

a) Facies association 5 (FA5)

Description. Described only from Râpa Dracului (Fig. 6) consists mostly of fine sediments with few thin intercalations of massive fine sandstones or siltstones (Pl. IV, Fig. 9). Thicker massive grayish muddy fine sandstones beds (with siltstones intercalations) develop at the base of the early Badenian deposits. Early Badenian planktonic foraminifera (Preorbulina, Orbulina) have been found in FA5.

Facies interpretation. The thicker grayish massive muddy fine sandstones beds at the bottom of FA5 (concentrated flows, Mulder and Alexander, 2001) with thin intercalations of massive siltstones, mudstones might be related to a reminiscent delta front affected by the early Badenian transgression. The sedimentation continued in a low subsidence setting (Krezsek and Filipescu, 2005) with fine sediments deposited as distal lobes (low density turbiditic deposits). These distal lobes were probably deposited in a distal shelf or deep marine environment containing typical early Badenian planktonic foraminifera, which are characteristic to the main stage of the sea-level rise (transgression).

\section{b) Facies association 6 (FA6)}

Description. It can be divided into two subfacies (6a and 6b) based on sedimentological features (Figs. 5-6). FA6a was identified in both investigated sections and include coarse tuffites with pumice (grain size from lapilli to ash) with medium size tuffites on top. Tuffites resulted from homogenous mixing between siliciclastic and/or limestone material with variable amount of pyroclastic fragments, composed mostly by vitric shards, crystaloclasts and pumice (Seghedi and Szákacs, 1991). Rip-up clasts (erosional basal lag) developed in a massive to a normal graded fabric (Pl. V, Fig. 5) at the base of FA6a. Only at Râpa Dracului the mudstones rip-up develop in a pseudo-imbrication pattern and have boulder sizes (P1. IV, Fig. 6). Cross-stratification or epsilon cross stratification develops with small oversplay crevasse channels (Pl. V, Figs. 2, 5; Pl. IV, Fig. 6). Facies association 6a ends with medium-coarse tuffites in massive to normally graded beds. The erosional contact between the FA6a and FA5 can be observed at Râpa Dracului (Pl. IV, Fig. 9).

FA 6b develops only at the upper part of the Pâglişa outcrop. It starts with massive to normally graded medium to coarse tuffites (with fine conglomenrates and pumice intercalations) (Pl. V, Fig. 8) with rip-up clasts and deformational structures (load casts). Grain size decreases towards the top and medium to coarse tuffites are replaced by medium to medium-fine tuffites (locally with pumice) with rip-up clasts and flutes (North West to South East paleoflow direction, Pl. V, Fig. 3). An interesting feature is the presence of fine green tuff rafts. It is interbedded with the FA7 towards the top of the Pâglişa section.

Facies interpretation. Overall FA6a has a normally graded pattern, which is typical for a channel like structure (finning upward trend). These deposits represent large meandering channels that have an erosional base, followed by meandering bars with small oversplay crevasse channels.

FA $6 b$ is made of smaller stacked submarine channels compared to FA6a and has a fining upward trend with erosional boundaries (e.g., fine tuff rafts) typical for a channel like deposit. These channels could have been highly influenced by the volcanic activity. 
c) Facies association 7 (FA7)

Description. The main unit of FA7 developed between the lower FA6a and upper FA6b at Pâglișa. At Râpa Dracului these facies association can be observed in top of the FA6a but detailed investigation was not possible due to the difficult geomorphology. FA7 contains the typical green fine vitroclastic Dej Tuff. Grain size varies from fine to medium-fine and rarely to medium tuffs (with pumice), tuffites with detritic mudstones, siltstones (?hemipelagites) (Pl. V, Fig. 7). These fine, finemedium sediments are massive, but reverse grading develops in top of the fine tuff beds because of the pumice (Pl. V, Fig. 6). Bioturbations (Cruziana type) develops on top of the Pâglişa outcrop (Pl. V, Fig. 4). Oxidised vegetal material, horizontal laminations, ripples marks also occur in fine tuffites. The fine siliciclastic sediments are massive or laminated.

Facies interpretation. FA7 is the result of fall-out sedimentation or redeposited low-density turbidites. The thin organic rich laminated mudstones (shalestones) were deposited due to low hydrodynamics that caused a decrease in the oxygen level and permitted the conservation of the organic material.

The Cruziana ichnofacies from the top of Dej Tuff indicates a sublitoral zone (marine offhore) with normal salinity, low hydrodinamics sometimes exposed to storm waves.

Based on the facies associations, the depositional environment of Hida Formation present at Pâglişa and Dej (Râpa Dracului section) outcrops can be interpreted as part of a distal fan delta environment characterize by numerous sediment gravity flows associated deposits. The age of this environment is upper lower Miocene (Burdigalian/Karpatian), as proven by the foraminifera and calcareous nannoplankton assemblages identified in the mudstones intercalations. Fan deltas develop in subaqueous (submarine in this case) environments as the submarine extension of the alluvial fans. Commonly they were dominated by various non-cohesive sediments originating from turbiditic flows (sensu Mulder and Alexander, 2001). Characters of delta front and a prodelta were identified in both investigated sections. The alluvial fan settings have not been identified. Sandy delta front develops at outcrop scale in a tabular geometry (lobes) with lenticular/sheet conglomerate beds (Săsăran, 1997) with rare intercalations of massive to laminated mudstones.

A coarsening upward trend can be observed, which indicates the progradation of the fan deltaic deposits $(\mathrm{FA} 1 \rightarrow$ FA2 $\rightarrow$ FA3 $\rightarrow$ FA4 at Pâglişa section and FA1 $\rightarrow$ FA4 for the Râpa Dracului section). This implies a vertical succession where proximal facies gradually replace the distal facies in time (Martins-Neto and Cătuneanu, 2010). The fan-delta probably developed as response to the tectonic activity (Pienides thrusting), which uplifted the adjacent source area.

The paleocurrent directions (ripples, dunes and scours) are strongly unidirectional and suggest a north-western source area. This is also supported by the sense of shear flame structures and of fine gravel imbrications.

For the Dej Formation we consider that FA5, FA6 and FA7 developed in self margin to deeper marine settings. Keeping in mind the early Badenian transgression conditions, FA6a erodes the distal lobes of FA5 probably because of the high volcanic activity. FA7 contains fall-out tuffs (+ fine siliciclastic sediments), which are massive, not affected by wave energy or volcanic activity. These might be interpreted as FA7 was deposited in distal self or deep marine conditions, where planktonic foraminifera dominated. The top of the last FA7 in the Paglisa section contains the Cruziana ichnofacies that suggests offshore conditions.
FA6b (Paglişa) eroded the distal facies association because of the high sedimentary input provided by the volcanic activity. FA5, FA6 and most of FA7 developed in deep marine settings.

\section{CONCLUSIONS}

Based on planktonic foraminifera two biozones have been clearly identified: Streptochilus-Bolivina and Orbulina suturalis Zones. Planktonic foraminifera correspond to distinct intervals on the relative sea-level curve: Streptochilus - eutrophic environment associated to the initial sea-level rise (lowstand systems tract), Orbulina - oligotrophic environment associated to the main phase of the transgression (transgressive systems tract).

Based on grain size and primary sedimentary structures 4 facies associations have been distinguished for the Hida Formation in which a "coarsening upward" trend was dominant. The depositional system belongs to a distal fan-delta with prodelta to delta front depositional environments characterize by numerous sediment gravity flows associated deposits.

Three facies associations have been separated for the Dej Formation. Overall, the first facies association is represented by distal lobes (deep marine to offshore settings). The FA6 comprises large meandering channels to small channels, highly influenced by the volcanic input. FA7 is made of fall-out deposits and low density turbiditic deposits with bioturbations pointing out a more quiet volcanic activity.

All these features suggest that the Early-Middle Miocene transition in the north-western Transylvanian Basin was produced in a transgressive context strongly influenced by the tectonic activity and associated volcanism.

Acknowledgments. This study was possible with the financial support of the Sectoral Operational Programme for Human Resources Development 2007-2013, co-funded by the European Social Fund, under the project number POSDRU 89/1.5/S/60189 „Postdoctoral Programs for Sustainable Development in a Knowledge Based Society". Răzvan Bercea wishes to thank Raluca Munteanu and Şerban Bogdan for their help in the field. The authors are grateful to the anonymous reviewers for suggestion that improved the present manuscript.

\section{REFERENCES}

Beldean, C., Filipescu, S. \& Bălc, R. 2010, An Early Miocene biserial foraminiferal event in the Transylvanian Basin (Romania). Geologica Carpathica, 61 (3): 227-234. http://dx.doi.org/10.2478/v10096-010-0013-4

Beldean, C., Filipescu, S. \& Bălc, xR. 2012, Paleoenvironmental and biostratigraphic data for the Early Miocene of the north-western Transylvanian Basin based on planktonic foraminifera. Carpathian Journal of Earth and Environmental Science, 7 (1): 171-184.

Berggren, W.A., Kent, D.V., Swisher III, C.C. \& Aubry, M.P.A. 1995, Revised Cenozoic geochronology and chronostratigraphy. In Geochronology, time scale and global stratigraphic correlations: a unified temporal framework for a historical geology (Berggren W.A., Kent D.V., Hardenbol J., Eds.), Society of Economic Paleontologists and Mineralogists, Special Publication 54: 129-212.

Bhattacharya, J.P., Davies, R.K. 2001, Growth faults at the prodelta to delta-front transition, Cretaceous Ferron sandstone, Utah. Marine and Petroleum Geology, 18: 525-534. http://dx.doi.org/10.1016/S0264-8172(01)00015-0 
Brönnimann, P., Resig, J. 1971, A Neogene globigerinacean biochronologic time-scale of the southwestern Pacific. In Initial Reports of the Deep Sea Drilling Project (Winterer, E.L., Riedel, W.R., Broennimann, P., Gealy, E.L., Heath, G.R., Kroenke, L.W., Martini, E., Moberly, R. Jr., Resig, J.M., Worsley, T.R. Eds.), College Station, Texas: Ocean Drilling Program 7: 1235-1469.

Chira, C., Bălc, R. 2002, Miocene calcareous nannofossils from Dej - Reteag - Ciceau area (Transylvanian Basin, Romania): Biostratigraphical importance and palaeoeocological data. Acta Paleontologica Romaniae, 3: 53-65.

Chira, C., Szabo, E. \& Ianoliu, C. 2000, Badenian (Middle Miocene) calcareous nannofossils from Pâglişa (Cluj District): biostratigraphical importance. Studia $U B B$ Geologia, XLV (2): 21-31.

de Leeuw, A. 2011, Paleomagnetic and geochronologic constraints on the Miocene evolution of semi-isolated basins in southeastern Europe. PhD Thesis, Utrecht University, The Netherlands, $190 \mathrm{p}$.

de Leeuw, A., Filipescu, S., Maţenco, L., Krijgsman, W., Kuiper, K. \& Stoica, M. 2013, Paleomagnetic and chronostratigraphic constraints on the Middle to Late Miocene evolution of the Transylvanian Basin (Romania): Implications for Central Paratethys stratigraphy and emplacement of the Tisza-Dacia plate. Global and Planetary Change, 103: 82-98. http://dx.doi.org/10.1016/j.gloplacha.2012.04.008

Dumitrică, P., Gheța, N. \& Popescu, G. 1975, New data of the biostratigraphy and correlation of the Middle Miocene in the Carpathian area. Dări de Seamă ale Şedinţelor Institutului de Geologie şi Geofizică, 61 (4): 65-84.

Filipescu S., Gîrbacea R. 1997, Lower Badenian sea level drop on the western border of the Transylvanian Basin: foraminiferal paleobathymetry and stratigraphy. Geologica Carpathica, 48 (5): 325-334.

Flower, B.P. 1999, Data report: Planktonic foraminifers from the subpolar North Atlantic and Nordic Sea: Sites 980-987 and 907. In Proceedings of the Ocean Drilling Program, Scientific Results (Raymo, M.E., Jansen, E., Blum, P., Herbert, T., Eds.), College Station, Texas, Ocean Drilling Program 162: 19-34.

Gani, M.R., Bhattacharya, J.P. 2007, Basic building blocks and process variability of a Cretaceous delta: internal facies architecture reveals a more dynamic interaction of river, wave, and tidal processes than is indicated by external shape. Journal of Sedimentary Research, 77: 284-302. http://dx.doi.org/10.2110/jsr.2007.023

Hallock, P., Premoli Silva, I. \& Boersma, A. 1991, Similarities between planktonic and larger foraminiferal evolutionary trends through Paleogene paleoceanographic changes. Palaeogeography, Palaeoclimatology, Palaeoecology, 83: 49-64. http://dx.doi.org/10.1016/0031-0182(91)90075-3

Haq, B.U., Hardenbol, J. \& Vail, P.R. 1988, Chronology of fluctuating sea level since the Triassic. Science, 235: 1136-1167.

Hardenbol J., Thierry J., Farley M.B., Jacquin T., De Graciansky P.C. \& Vail P.R. 1998, Mesozoic and Cenozoic sequence chronostratigraphic framework of European Basins. In Mesozoic and Cenozoic sequence stratigraphy of European Basins (de Graciansky, P.C., Hardenbol, J., Jacquin, T., Vail, P.R., Eds.), Society for Sedimentary Geology, Special Publication 60: 3-13.

Harzhauser, M., Daxner-Höck, G., Boon-Kristkoiz, E., Ćoric, S., Mandic, O., Miklas-Tempfer, P., Roetzel, R., Rögl, F., Schultz, O., Spezzaferri, S., Ziegler, R. \& Zorn, I. 2003, Paleoecology and biostratigraphy of the section Mühlbach (Gaindorf Formation, lower Middle Miocene, Lower Badenian, Austria). Annalen des Naturhistorischen Museums in Wien, 104 (A): 323-334.
Hilgen, F.J., Lourens, L.J. \& Van Dam, J.A. 2012, The Neogene Period. In The Geologic Time Scale 2012, vol. 2 (Gradstein, F.M., Ogg, J.G., Schmitz, M.D., Ogg, G.M., Eds.), Elsevier, p. 923-987. http://dx.doi.org/10.1016/B978-0-444-59425-9.00029-9

Hofmann, K. 1879, Bericht über die im östlichen Teile des Szilagyer Comitates wahrend der Sommercampagne 1878 vollfuhrten geologischen Specialaufnahmen. Földtani Közlöny, XI: 317-329.

Kennett, J.P., Srinivasan, M.S. 1983, Neogene planktonic foraminifera: a phylogenetic atlas. Hutchinson Ross Publishing Company, 265 p.

Koch,A. 1900, Die Tertiärbildungen des Beckens der Siebenbürgische Landestheile. Il Neogene Abtheilung, Budapest, 370 p.

Kováčová, P., Hudáčková, N. 2005, Lower/Middle Badenian foraminiferal associations from the Vienna Basin (Slovak part) and Carpathian Foredeep: Biostratigraphy and paleoecology. Slovak Geological Magazine, 11 (4): 233-248.

Krézsek, C., Filipescu, S. 2005, Middle to Late Miocene sequence stratigraphy of the Transylvanian Basin (Romania). Tectonophysics, 410 (1-4): 437-463. http://dx.doi.org/10.1016/j.tecto.2005.02.018

Krézsek, C., Bally, A.W. 2006, The Transylvanian Basin (Romania) and its relation to the Carpathian fold and thrust belt: Insights in gravitational salt tectonics. Marine and Petroleum Geology, 23 (4): 405-442.

http://dx.doi.org/10.1016/j.marpetgeo.2006.03.003

Krézsek, C., Filipescu, S., Silye, L, Matenco, L. \& Doust, H. 2010, Miocene facies associations and sedimentary evolution of the Southern Transylvanian basin (Romania): implications for hydrocarbon exploration. Marine and Petroleum Geology, 27: 191-214.

http://dx.doi.org/10.1016/j.marpetgeo.2009.07.009

Kroon, D., Williams, T., Pirmez, C., Spezzaferri, S., Sato, T. \& Wright, J.D. 2000, Coupled early Pliocene - middle Miocene biocyclostratigraphy of Site 1006 reveals orbitally induced cyclicity patterns of Great Bahama Bank carbonate production. In Proceedings of the Ocean Drilling Program, Scientific results (Swart, P.K., Eberli, G.P., Malone, M.J., Sarg, J.F., Eds.), College Station, TX 166: 155-166.

Leigh, S., Hartley, J.A. 1992, Mega debris flow deposits from the Oligo-Miocene Pinodos foreland basin, western mainland Greece: implications for transport mechanism in ancient deep marine basins. Sedimentology, 39: 1003-1012. http://dx.doi.org/10.1111/j.1365-3091.1992.tb01993.x

Lourens, L., Hilgen, F., Shackleton, N.J., Laskar, J. \& Wilson, D. 2004, The Neogene Period. In A geologic time scale 2004 (Gradstein, F.M., Ogg, J.G., Smith, A.G., Eds.). Cambridge University Press, Cambridge, p. 409-440.

Lowe, D.R. 1982, Sediment gravity flows; II: Depositional models with special reference to the high-density turbidity currents. Journal of Sedimentary Petrology, 52: 279-298.

Maiorano, P., Monechi, S. 1998, Revised correlations of Early and Middle Miocene calcareous nannofossil events and magnetostratigraphy from DSDP Site 563 (North Atlantic Ocean). Marine Micropaleontology, 35: 235-255.

http://dx.doi.org/10.1016/S0377-8398(98)00019-X

Mandur, M.M.M. 2009, Calcareous nannoplankton biostratigraphy of the Lower and Middle Miocene of the Gulf of Suez, Egypt. Australian Journal of Basic and Applied Sciences, 3 (3): 2290-2303.

Martini, E. 1971, Standard Tertiary and Quaternary calcareous nannoplankton zonation. In Proceedings of the II Planktonic Conference, Roma, 1970 (Farinacci, A., Ed.), Tecnoscienza, p. 739-785.

Martins-Neto, M.A., Catuneanu, O. 2010, Rift sequence stratigraphy. Marine and Petroleum Geology, 27: 247-253. http://dx.doi.org/10.1016/j.marpetgeo.2009.08.001 
Mészáros, N., Filipescu, S. 1991, Le nannoplankton du Complex du Tuf de Dej (Râpa Dracului). In The Vulcanic Tuffs from the Transylvanian Basin (Bedelean, I., Ghergari, L., Mârza, I., Mészáros, M., Nicorici, E., Petrescu, I., Eds.), Cluj-Napoca, p. 79-82.

Mészáros, N., Ianoliu, C. \& Pion, N. 1976, Nannoplankton in the Hida Strata from Hida and stratigraphic significance. Dări de Seamă ale Şedinţelor Institutului de Geologie şi Geofizică, LXIII (4): 155-161 (in Romanian).

Mulder, T., Alexander, J. 2001, The physical character of subaqueous sedimentary density flows and their deposits. Sedimentology, 48 (2): 269-299. http://dx.doi.org/10.1046/j.1365-3091.2001.00360.x

Popescu, G. 1970, Planktonic foraminiferal zonation in the Dej Tuff Complex. Revue Roumaine de Géologie, Géophysique et Géographie. Géologie, 12 (2): 189-203.

Popescu, G. 1975, Études des foraminifères du Miocène inférieur et moyen du nordouest de la Transylvanie. Mémoires - Institut de Géologie et de Géophysique, XXIII: 1-121.

Premoli Silva, I., Violanti, D. 1981, Cenozoic planktonic foraminifer biostratigraphy of the Deep Sea Drilling Project Hole 462, Nauru Basin (Western Equatorial Pacific), and distribution of the pelagic components. In Initial reports of the deep sea drilling project (Larson, R.L., Schlanger, S.O., Eds.), U.S. Government Printing Office 61: 397-422.

Resig, J. 1989, Stratigraphic distribution of late Neogene species of the planktonic foraminifer Streptochilus in the Indo-Pacific. Micropaleontology, 35 (1): 49-62. http://dx.doi.org/10.2307/1485536

Rio, D., Cita, M.B., Iaccarino, S., Gelati, R. \& Gnaccolini, M. 1997, Langhian, Serravallian, and Tortonian historical stratotypes. In Miocene Stratigraphy: An integrated approach (Montanari, A., Odin, G.S., Coccioni, R., Eds.). Developments in paleontology and stratigraphy, 15: 57-87.
Rögl, F. 1985, Late Oligocene and Miocene planktic foraminifera of the Central Paratethys. In Plankton stratigraphy (Bolli, H.M, Saunders, J.B., Perch-Nielsen, K., Eds.), Cambridge University Press, 1: 315-328.

Rögl, F., Ćorić, S., Harzhauser, M., Jimenez-Moreno, G., Kroh, A., Schultz, O., Wessely, G. \& Zorn, I. 2008, The Middle Miocene Badenian stratotype at Baden-Sooss (Lower Austria). Geologica Carpathica, 59 (5): 367-374.

Săsăran, F.E. 1997, Hida Formation study in the SurducDej area, sedimentological and genetical significance. Unpublished BSc Thesis, Babes-Bolyai University, ClujNapoca, 64 p (in Romanian).

Seghedi, I., Szakács, A. 1991, “The Dej Tuff” from DejCiceu area: some petrographical, petrochemical and volcanological aspects, In The Vulcanic Tuffs from the Transylvanian Basin (Bedelean, I., Ghergari, L., Mârza, I., Mészáros, M., Nicorici, E., Petrescu, I., Eds.), ClujNapoca, p. 135-146.

Szakács, A., Pécskay, Z., Silye, L., Balogh, K., Vlad, D. \& Fülöp, A. 2012, On the age of the Dej Tuff, Transylvanian Basin (Romania). Geologica Carpathica, 63 (2): 139-148. http://dx.doi.org/10.2478/v10096-012-0011-9

Tanaka, J., Maejima, W. 1995, Fan-delta sedimentation on the basin margin slope of the Cretaceous, strike-slip Izumi Basin, southwestern Japan. Sedimentary Geology, 98: 205-213. http://dx.doi.org/10.1016/0037-0738(95)00033-5

Tischler, M. 2005, A combined structural and sedimentological study of the Inner Carpathians at the northern rim of the Transylvanian basin (N. Romania). $\mathrm{PhD}$ Thesis, Institut für Geologie-Paläontologie, Universität Basel, 136 p.

Turco, E., Cascella, A., Gennari, R., Hilgen, F.J., Iaccarino, S.M. \& Sagnotti, L. 2011, Integrated stratigraphy of the La Vedova section (Conero Riviera, Italy) and implications for Langhian GSSP. Stratigraphy, 8: 89-110. 


\section{PLATE I}

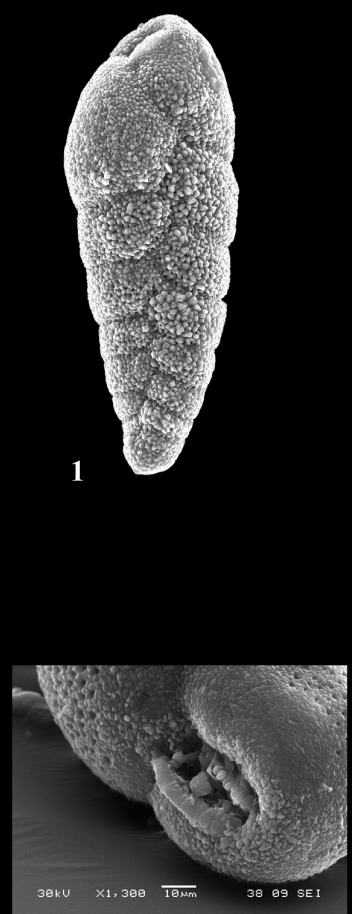

3a

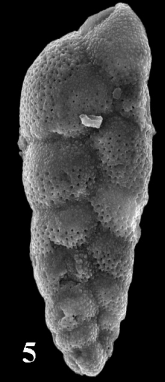

6
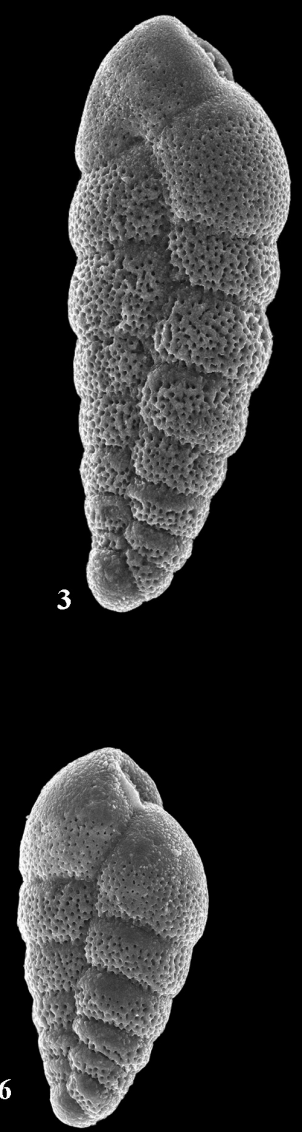

$4 a$
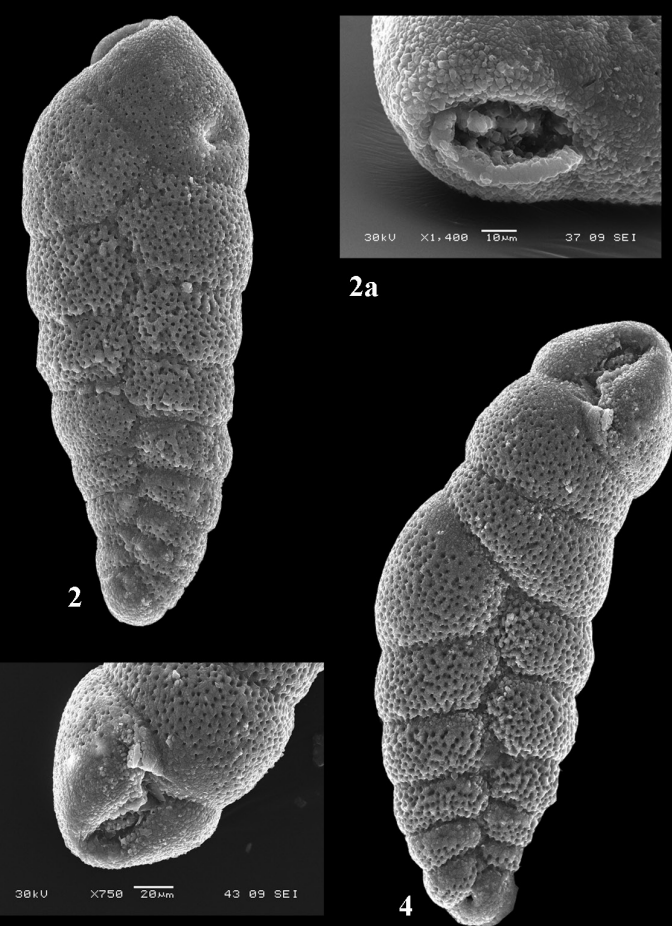

$2 \mathbf{a}$
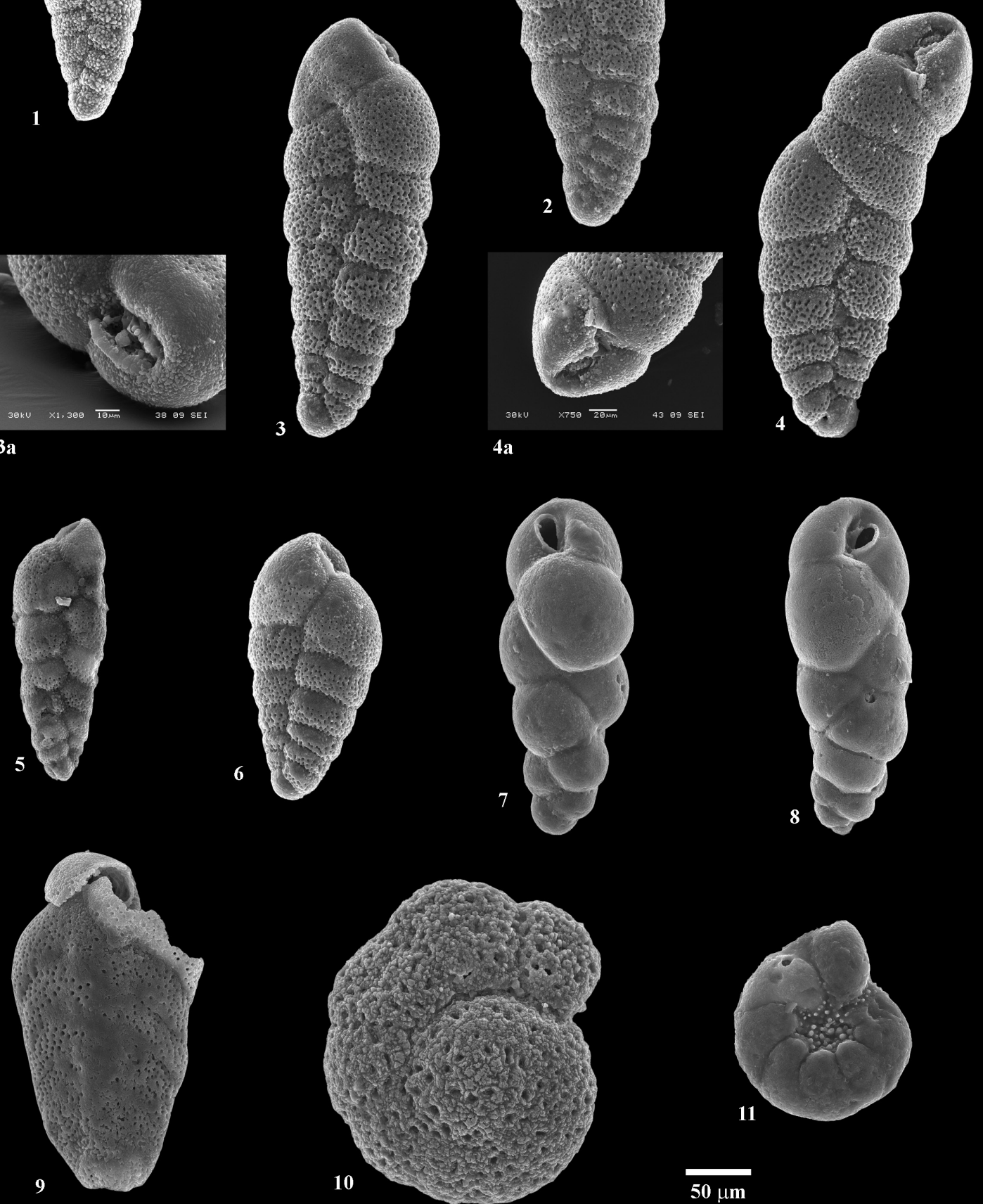

$\mathbf{5 0} \mu \mathrm{m}$

Plate I. Foraminiferal assemblages from Hida Formation.

Figs. 1-6. Streptochilus pristinum Brönnimann \& Resig.

Figs. 7-8. Bulimina elongata d'Orbigny.

Fig. 9. Bolivina dilatata dilatata Reuss.

Fig. 10. Cibicidoides sp.

Fig. 11. Protelphidium roemeri (Cushman). 


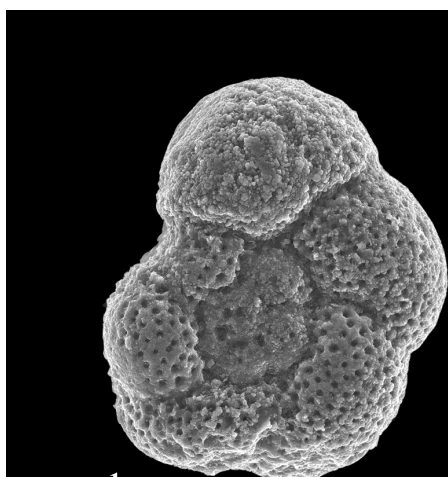

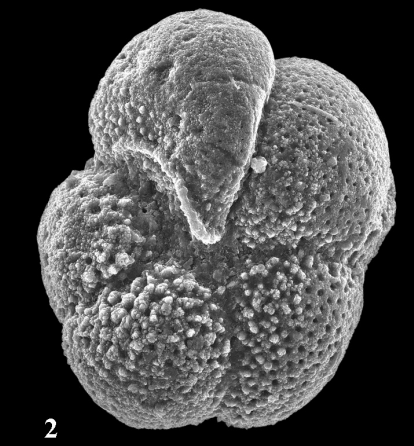
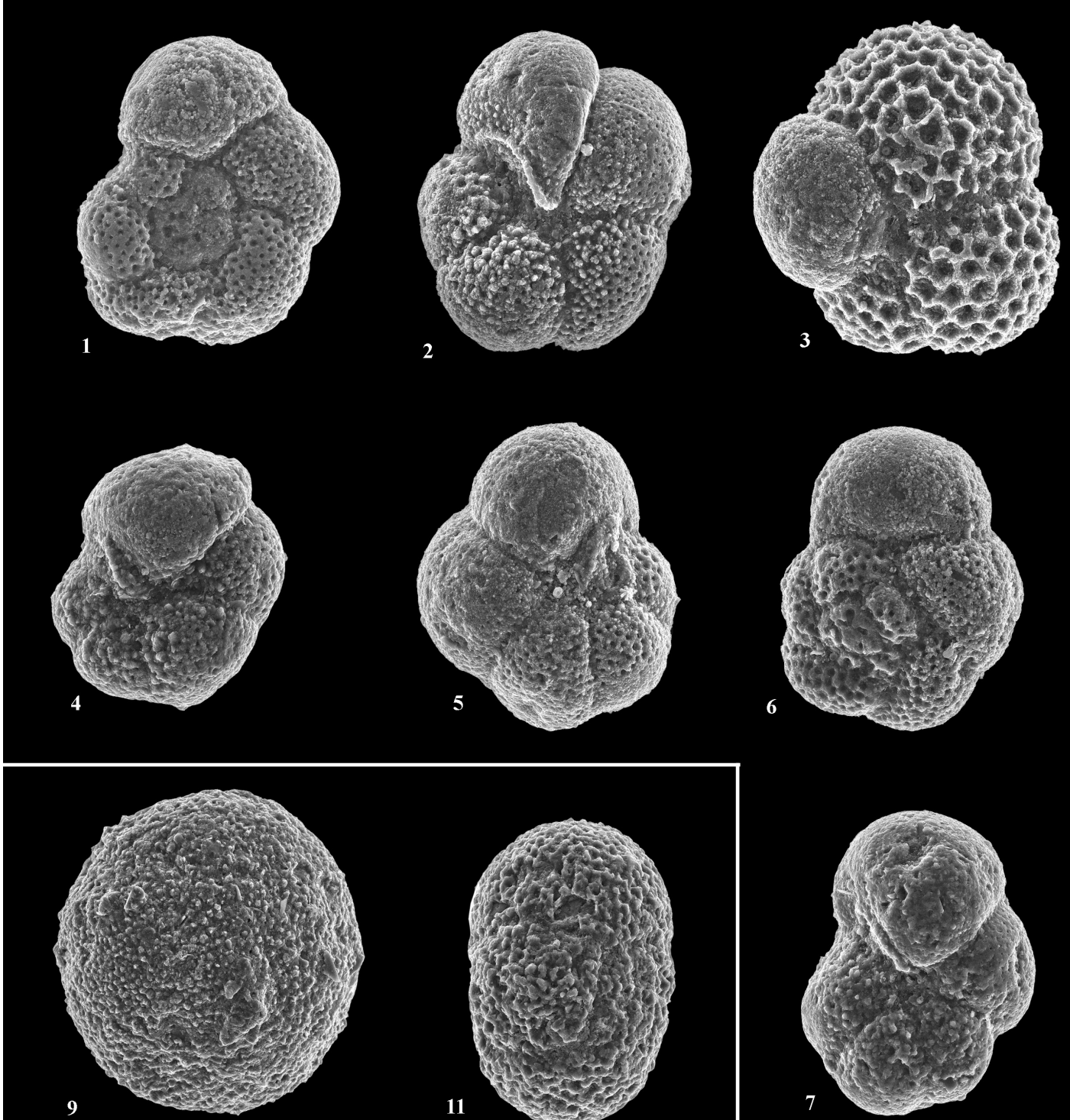

11
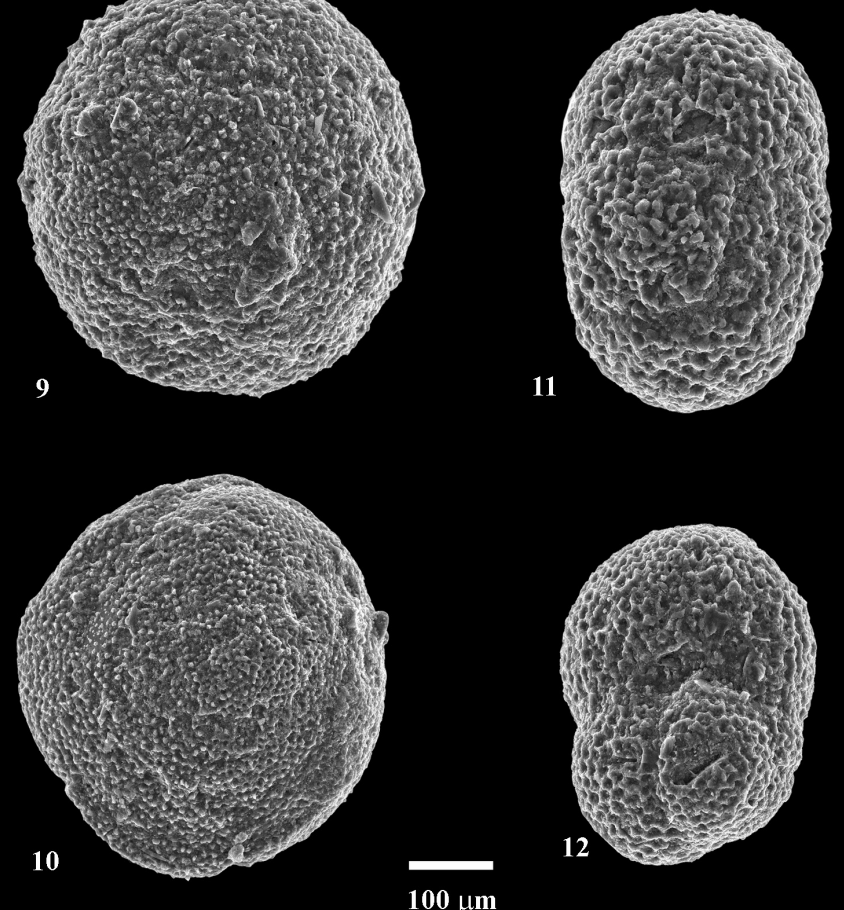

PLATE II 

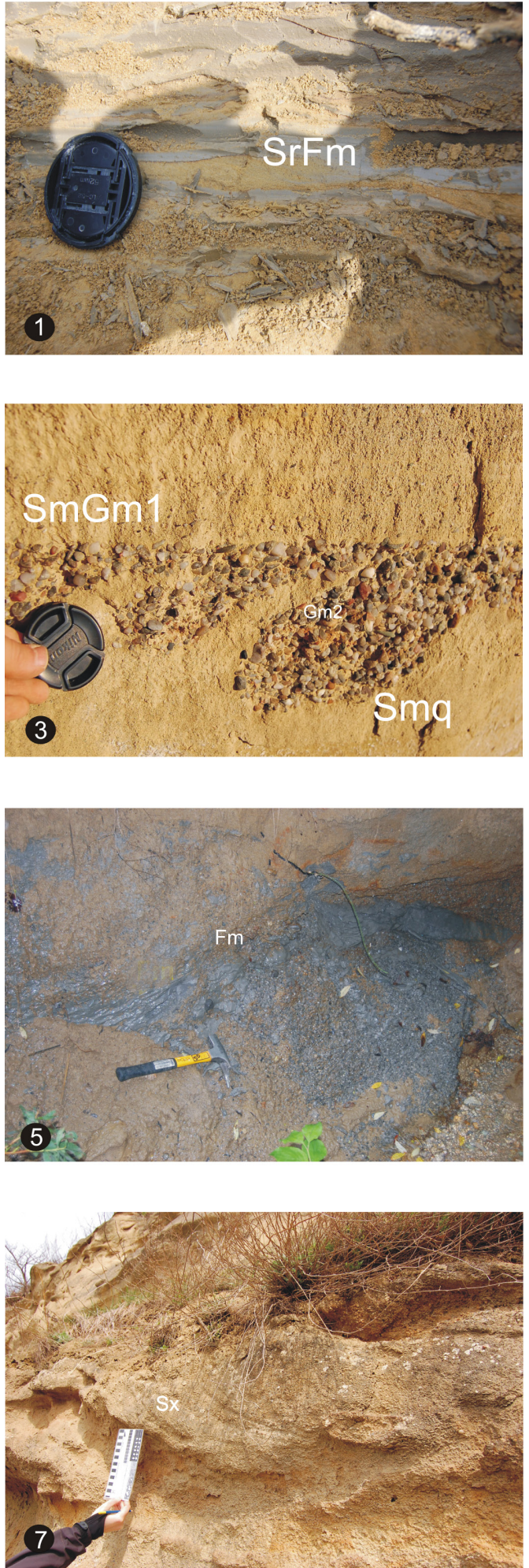

Plate III. Sedimentary facies from Pâglişa.

\section{PLATE III}
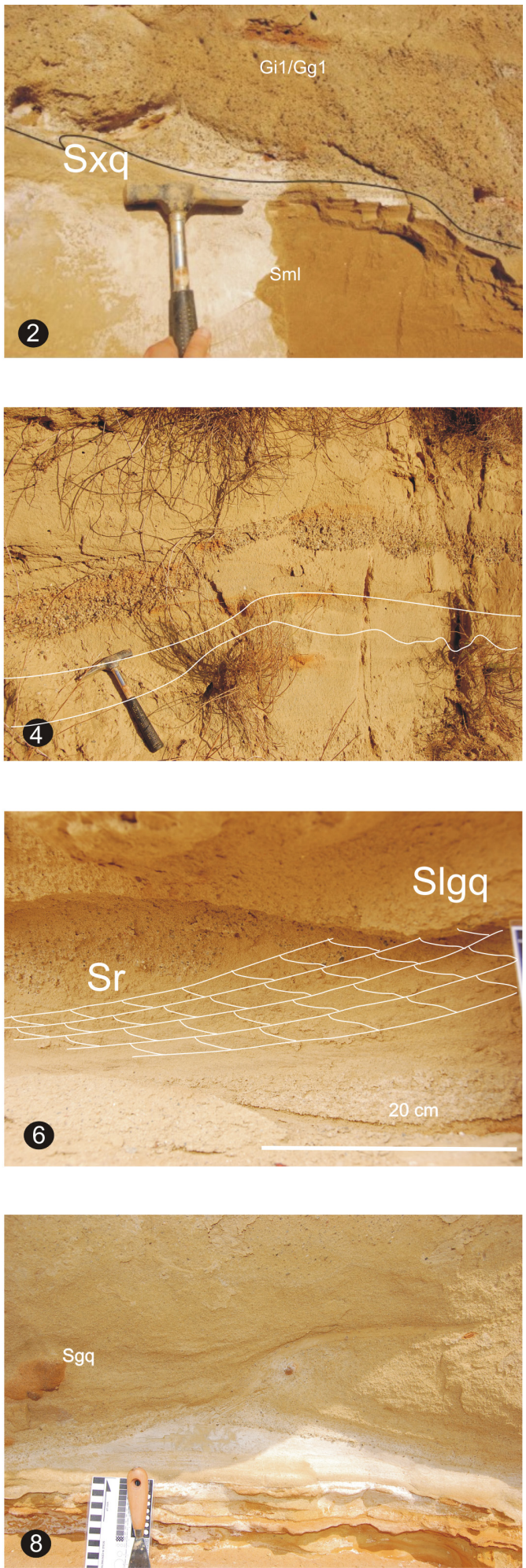

Fig. 1. Lenticular sand ripples in a mud framework in F.A. 1.

Fig. 2. Scour erosional limit that cuts a fine gravelly sand dune and the laminated sand with rip-up clasts developed (F.A. 2).

Fig. 3. a(p)a(i)-type imbrication of the granules; load structures (F.A. 2).

Fig. 4. Amalgamated bipartite beds (F.A. 2).

Fig. 5. Massive mud, interpreted as a interchannel/interlobe fine deposits (F.A. 2).

Fig. 6. Climbing ripples (F.A. 3).

Fig. 7. Gravelly medium-coarse sandstones sigmoidal dune.

Fig. 8. Flame structures bipartite layers (F.A. 3). 

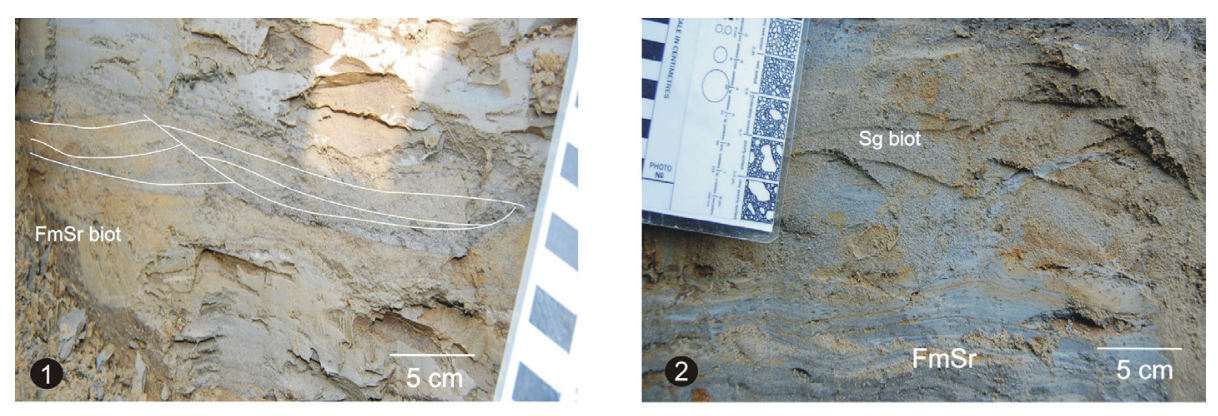

PLATE IV
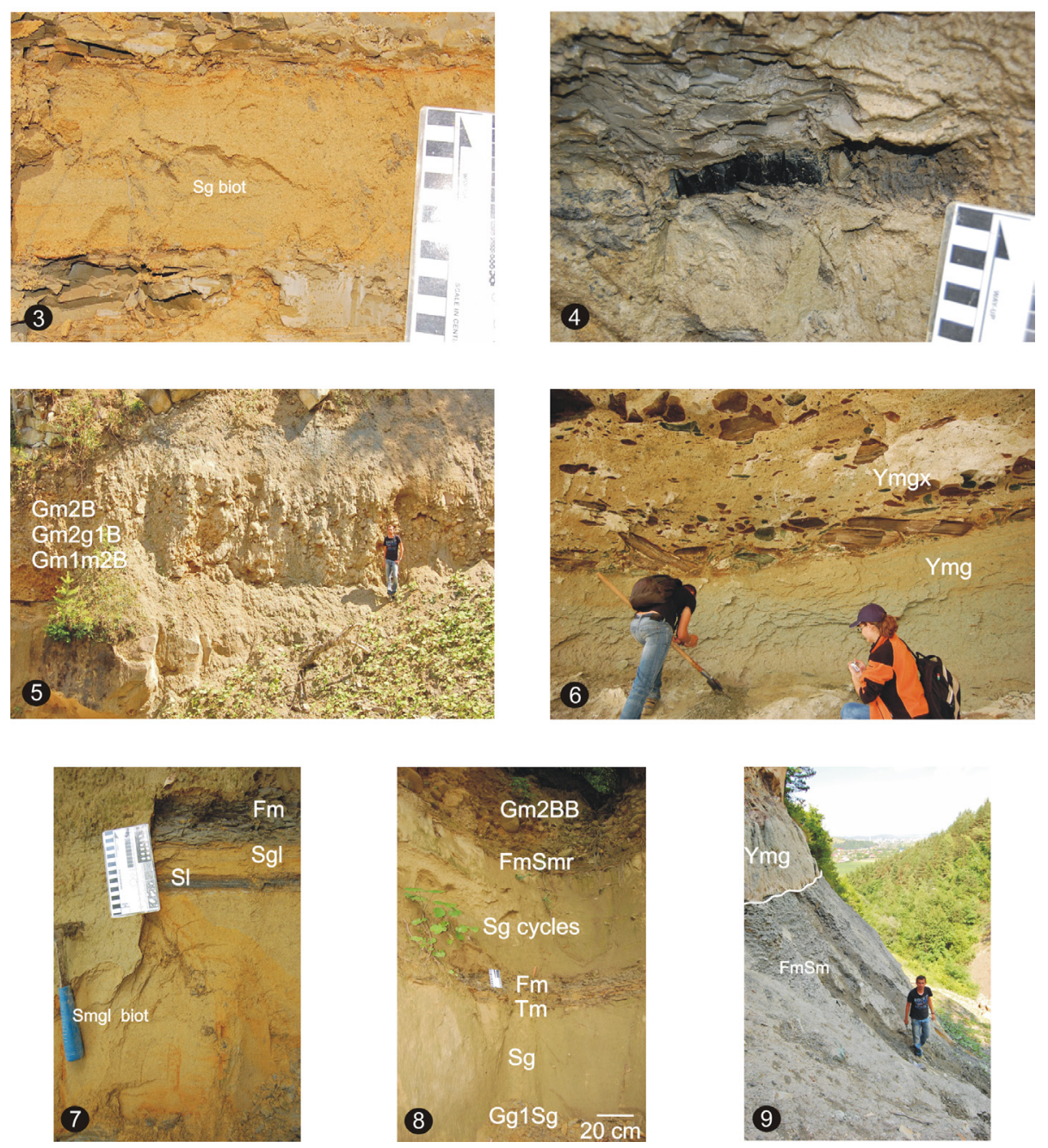

Plate IV. Sedimentary facies from Dej (Râpa Dracului).

Fig. 1. Oblique view of lenticular ripple marks structures partly destroyed by bioturbations (F.A. 1).

Fig. 2. Lenticular ripple mark to bioturbated, normal graded sands (F.A. 1) of the Hida Formation.

Fig. 3. Vertical and horizontal burrows in normal graded sand bounded by massive mud (F.A. 1).

Fig. 4. Coal fragment (lignite) in normal graded, laminated, and rippled fine-medium sand caped by massive mud (F.A. 1).

Fig. 5. A $2.5 \mathrm{~m}$ sandy gravels stack (F.A. 4).

Fig. 6. Pseudo-imbricated rip-up clasts developed in mixed vulcanoclastic-siliclastic point bars which were part of some meandering submarine channels (F.A. 6a).

Fig. 7. Thick normal graded sand bed with crude horizontal lamination towards the top; small coal chips; vertical and horizontal burrows in the sand unit.

Fig. 8. Distal delta front beds that consist of normal graded granules and medium-coarse sands to normal graded sand separated by rip-up level (erosional limit) (F.A. 1). In the upper part, sandy gravel (granules to boulders-orthoconglomerates) in the F.A. 4.

Fig. 9. Thick mud layers with thin intercalations of massive sands (F.A. 5); the erosional contact between the siliciclastic and the mixed vulcanoclastic/siliciclastic of the Dej Formation is visible. 

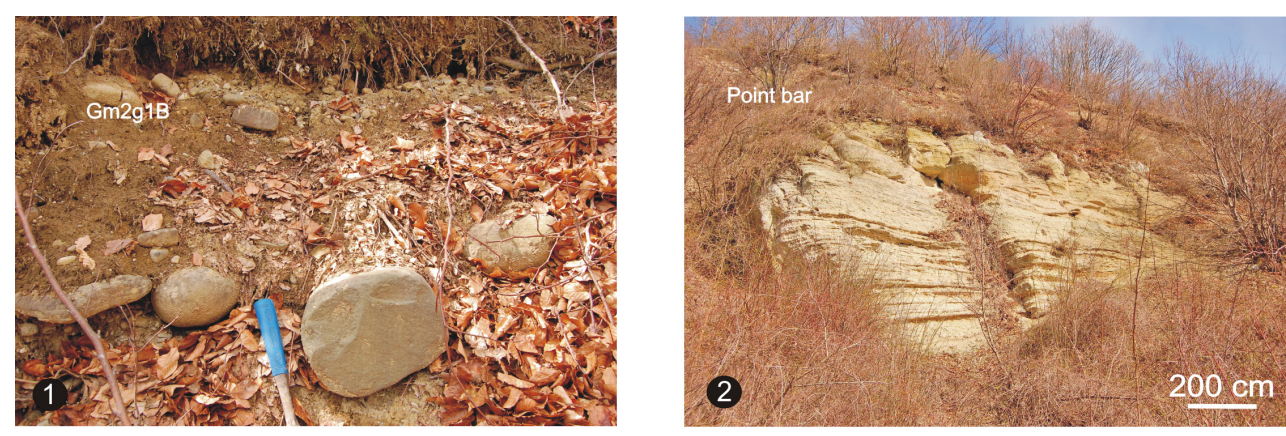

PLATE V
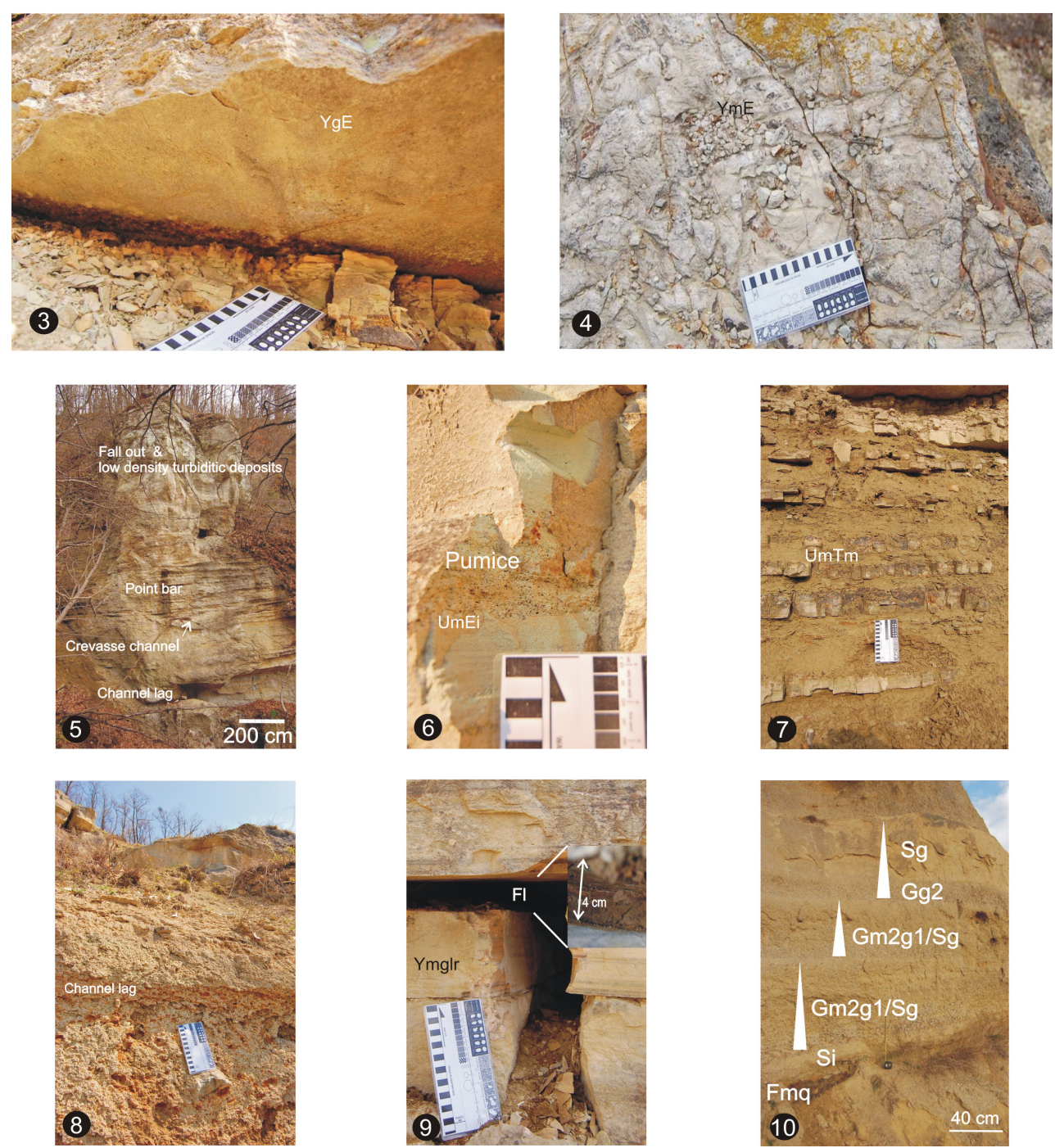

Plate V. Sedimentary facies from Pâglişa.

Fig. 1. Sandy gravels (with boulders) lenses in top of the Hida Formation (F.A. 4).

Fig. 2. Point bars-perpendicular view to outcrop (F.A. 5a) followed by fall-out volcanic towards the top of the picture (F.A. 6).

Fig. 3. Flute structures at the base of a smaller mixed vulcanoclastic/siliciclastic submarine channel (F.A. 5b).

Fig. 4. Bioturbations (?Cruziana ichnofacies) on top of the exposed Dej Formation outcrop (F.A. 6).

Fig. 5. Stacked mixed vulcanoclastic/siliciclastic submarine meandered channels with channel lag deposits at the base, crevasse splays and point bars in the middle part.

Fig. 6. Massive to reverse grading tuff with pumice - middle part of the exposed Dej Formation outcrop (F.A. 6).

Fig. 7. Massive clayey silt with massive tuff couplets - middle part of the outcrop (F.A. 2) (scale bar: $20 \mathrm{~cm}$ ).

Fig. 8. Mixed vulcanoclastic/siliciclastic submarine channel lag of the second finning upward sequence (F.A. 5b).

Fig. 9. Massive normal graded, laminated reworked tuffs with some thin cross-lamination; dark brownish organic laminated mud (F.A. 5b).

Fig. 10. Bipartite beds of sandy gravel and medium-fine sands; deformed and scoured mud bed. 